Article

\title{
Strengthening Agroecology with the Political Pedagogy of Peasant Organisations: A Case Study of Baserritik Mundura in the Basque Country
}

\author{
Beatriz Casado ${ }^{1}\left[\right.$, Leticia Urretabizkaia ${ }^{1}$, Mirene Begiristain-Zubillaga ${ }^{2}{ }^{(\mathbb{C}}$ and Zesar Martinez ${ }^{3, *}$ \\ 1 Institute of Studies on Development and International Cooperation, University of the Basque Country, \\ Zubiria Etxea, Avda. Lehendakari Agirre, 81, 48015 Bilbao, Spain; beatrize8@hotmail.com (B.C.); \\ letiuski@hotmail.com (L.U.) \\ 2 Department of Finance Economy II, Faculty of Economics and Business, \\ University of the Basque Country (UPV-EHU), Plaza de Oñati 1, 20018 Donostia-San Sebastián, Spain; \\ mirene.begiristain@ehu.eus \\ 3 Department of Sociology and Social Work, Faculty of Communication and Social Sciences, \\ University of the Basque Country (UPV-EHU), Sarriena, 48940 Leioa, Spain \\ * Correspondence: zesar.martinez@ehu.eus; Tel.: +34-(65)-5700500
}

check for updates

Citation: Casado, B.; Urretabizkaia,

L.; Begiristain-Zubillaga, M.;

Martinez, Z. Strengthening

Agroecology with the Political

Pedagogy of Peasant Organisations:

A Case Study of Baserritik Mundura

in the Basque Country. Sustainability

2022, 14, 2227. https://doi.org/

$10.3390 /$ su14042227

Academic Editor: Manuel González de Molina

Received: 6 January 2022

Accepted: 9 February 2022

Published: 16 February 2022

Publisher's Note: MDPI stays neutral with regard to jurisdictional claims in published maps and institutional affiliations.

Copyright: (c) 2022 by the authors Licensee MDPI, Basel, Switzerland. This article is an open access article distributed under the terms and conditions of the Creative Commons Attribution (CC BY) license (https:// creativecommons.org/licenses/by/ $4.0 /)$.

\begin{abstract}
La Vía Campesina organisations have identified the area of education and training as a strategic and priority arena of intervention to bring about change in the political-pedagogical perspective. This involves rethinking and redesigning the conventional training processes towards the collective experiences of learning, organisation, exchange and living. With this approach in mind, and based on the experiences and educational contributions made by peasant organisations, this paper presents the systematisation of the Baserritik Mundura experience, analysing and sharing the learning derived from this case study and establishing the integral role of the pedagogic proposal as an axis for systematisation. This analysis, from the logic of the systematisation of processes, promulgates the learnings of this agroecological training experience while exposing both its strengths and weaknesses. We present the learning linked to the pedagogic dimensions that, through a cross-over method, aim to create a multidimensional educational environment which transforms our subjectivities, practices and the beliefs that sustain them. This learning is presented in eight main areas related to: (1) organicity, (2) alternation, (3) the mystical and ludic-cultural dimension, (4) the contents, subjects and teaching team, (5) the proposal as a whole and its perspective of popular education and action research, (6) the transversality of the feminist perspective, (7) linguistic plurality and (8) the pedagogic political support of the process. In addition, we present considerations related to the learning identified in the systematisation itself. On the one hand, we look at the lack of training processes in the official university context related to an alternation system with an organicity linked to the territory, and the need for the practical development of a dynamic of the collective construction of knowledge with a view toward transforming the logics that underpin the existing hegemonic ideologies. On the other hand, we point out the need for a debate regarding the epistemological perspective and integral, experiential and emancipatory pedagogical perspectives. Even with their limitations and challenges, these proposals have great potential to train, organise, politicise, excite and connect people from different fields towards the construction of a fairer, healthier and more sustainable agroecological agri-food system, based on food sovereignty and the everyday lives of people
\end{abstract}

Keywords: agroecology; food sovereignty; training; peasantry; political pedagogies; systematisation of experiences

\section{Background and the Scope of Discussion}

The area of education and training has been identified by La Via Campesina (LVC) organisations as a strategic and priority arena of intervention [1] to dispute the control 
and appropriation of territories and agri-food systems by the corporate food regime [2] or food empire [3]. LVC also considers it a strategic area for challenging the control and appropriation of peasant knowledge and the imposition of the agro-industrial perspective in training and research centres and the construction of knowledge [4,5].

Recent years have seen an evolution in the analyses, strategies, proposals and conceptual frameworks generated by LVC on agroecology, food sovereignty, peasant rights, comprehensive and popular agrarian reform, etc. This evolution has been possible through a dialogue of knowledge between LVC's member organisations [6-10]. Through this dialogue, all the regions agree that the training offered by the official educational system does not meet their organisational needs nor is it useful for the development of their proposals. The official educational system trains technical people, graduates, specialists and researchers in different professional fields (agronomy, veterinary medicine, pedagogy, history, law, medicine, communication, etc.) under banking and standardising paradigms and methodologies that underpin the reproduction of the corporate agri-food system. Different studies have denounced this problem and, through these analyses, have drawn attention to the responses that LVC has put forward to meet its particular training needs from a political, ethical, pedagogical and methodological concept, in accordance with its proposals and strategies for social transformation [8,11-17].

LVC proposes that, through the production and consumption of food, agroecology is the way to advance towards food sovereignty and the necessary emancipatory transformations that this world-system requires. Training processes have been used strategically, in a climate of patriarchal and colonial capitalism, to hegemonise ideological imaginaries and, thus, promote subjectivities and ways of life related to capitalist values and interests. For this reason, LVC's training proposals, based on the interrelated defence of people, territories and food as a fundamental right of rural areas and not as a commodity, transcend the agricultural environment and pose the need to generate training processes with comprehensive methodologies that cross over into the multiple dimensions of our lives.

This approach calls for a change in the political-pedagogical perspective through rethinking and redesigning the conventional training processes towards collective experiences of learning, organisation, exchange and life. In an attempt to build training and education processes that respond to their organisational and political needs, most of the organisations that are articulated in LVC, fundamentally the Latin American ones, have begun to experiment with and develop political training processes that combine traditional educational moments (seminars, workshops, schools) with pedagogical processes that are experienced in the organisation of the movement and in daily life. All this implies thinking and building the processes from the logic of protagonism and the co-governance of the people who participate, taking into account the diversity that characterises them. This poses a real challenge and requires a profound transformation of the dimensions that constitute the pedagogical proposals, as this study will show.

This approach to political training is not just, or even primarily, the transmission of knowledge; it requires processes in which learning and training are not limited to the field of ideology and historical or political consciousness, but embrace the wider realms of daily life and the need for the development of counter-hegemonic capacities and proposals. In other words, training processes are required that address subjective issues (individual and collective), and non-cognitive dimensions such as complicity, values, mutual care, commitment, the construction of collective identity, emotional involvement, and the feeling of belonging to a collective process of emancipatory endeavours [18-24].

At the V International Conference in 2008, in recognition of the educational experiences developed by the organisations that comprise it, the creation and strengthening of political and agroecological training experiences were defined as a strategic priority [11]. An initial proposal for the design of LVC training was launched based on a series of philosophical, pedagogical and organisational principles [1]. The purpose of LVC training is to guide the construction of its own vocational training schools (self-organised), continental courses, visits to exchange experiences between different countries and regions and links with formal 
training providers to "influence universities to achieve a different and diverse education" (LVC, 2009:193). It was also considered strategic to dispute the formal educational spaces and educational policies to guarantee the access of rural populations to different educational levels, as well as explore the possibility for peasant organisations themselves to develop official courses in collaboration with official educational institutions. The act of challenging educational public policies in Brazil led to the milestone achievement of the National Programme of Education in Agrarian Reform (PRONERA).

Over the last 15 years, there has been a considerable increase in political and agroecological training processes and activities in all regions where LVC is organised (America, Asia, Africa, Europe and the Middle East); although, clearly, the global pandemic situation in the 2019-2021 period has slowed this trend.

Nevertheless, it is through the efforts of the organisations of the Latin American Coordinator of Rural Organizations (CLOC-Vía Campesina), especially those of the South American region, that huge contributions have been made towards the systematisation of their training experiences and to the mapping and identification of pedagogical and organisational elements that give political unity to their processes of political and agroecological training. The educational experience of the Landless Rural Workers' Movement (MST) of Brazil $[20,22,25,26]$ has been highlighted for its methodological and pedagogical referentiality. This explains why the majority of studies and publications on the existing political and agroecological training processes of LVC focus on experiences developed in Latin America $[10,13,17,19,27,28]$. However, there is a need to conduct deeper and more global research on the wide diversity of training experiences (official and own) that LVC organisations have launched.

One of the fundamental contributions of Latin American peasant organisations has been the elaboration, implementation and dissemination of methodologies for the construction and horizontal socialisation of knowledge. One of the most notable is the "campesino a campesino" $(\mathrm{CaC})$ methodology for agroecological training which promotes the construction of territorial processes that allow the massification of agroecology $[27,29,30]$. The massification and co-optation of the concept of agroecology by the capitalist hegemonic discourse is one of the great current challenges for LVC to dispute the territories [10,27,31]. Political and agroecological training processes (official and unofficial) are considered fundamental in this sense [27,32]. Among the different initiatives developed, of note is the network of the Latin American Institute of Agroecology of LVC (IALAS). Since 2005, at least eight IALAS have been launched in different Latin American countries, and all of them are spaces for political and agroecological training officially recognised by the educational system of each country, with the Florestan Fernandes National School (ENFF) of the MST movement being one of the main historical precedents and a methodological reference used for the implementation of the IALAs and other peasant training processes within and outside of LVC $[16,17]$.

Based on the learning of these training processes, LVC organisations have built an emerging and diverse peasant pedagogy [10,17], or agroecological peasant pedagogy [28], through training models and counter-hegemonic pedagogies based on reflections and theorisations of their training practices and, thus, affirming a pedagogical action-reflectiontheorisation [20] method within the popular education approach, building on the pedagogy of the oppressed as formulated by Paulo Freire [33]. Similarly, the influence of socialist pedagogy seen in educators such as Krúpskaya, Makarenko and Pistrak, or psycho-pedagogues such as Vygotsky is also notable, particularly when considering the organisation of a group of students into collectives, the educational centrality of essential work and the distinction of different educational times [26]. In other words, they practise popular education not only as a pedagogical method but also as a theory of knowledge and as a proposal for educational and political intervention for social transformation in an emancipatory sense.

Another fundamental contribution of the peasant organisations of the CLOC has been the construction of peasant and popular feminism (FCP) within it, which has permeated the rest of LVC, both in terms of its discourse and the way of doing things. The FCP 
promotes the need for a gender analysis, taking into account the different histories, roles and relationships of women from a perspective that articulates gender, class and ethnicity, and analyses the threats to women and Mother Earth which weaken economies, cultures and the lives of rural women around the world [34,35]. By acknowledging the contributions of the FCP both within LVC and at a discursive level, the gender inequality issues identified in the movement, science and the set of agricultural practices of agroecology can be addressed and women's own contribution to the movement and the construction and transformation of agroecological knowledge can be recognised [36]. Furthermore, and bearing in mind that the system to be deconstructed has been founded on complementary oppressions, by valuing the contributions made by the FCP in the construction of another model, an intersectional vision is incorporated that considers everyone [37]. In this sense, the LVC peasant organisations are also contributing to Latin American and global feminist construction from an intersectional perspective [38], although much remains to be analysed regarding the way in which this is permeating LVC policy.

Within this scenario, it is clear that studies that analyse and systematise the experiences of political and agroecological training in the Global North, which put LVC's educational policy into practice, are still scarce both with regard to their own training processes and collaboration with educational institutions [32,39-43]. We aim to address this imbalance in a small way by presenting our use of this systematisation by adapting the elements and principles that characterise the agroecological training processes of LVC and the lessons learned to the Basque reality. The objective of this study is to analyse and share the learnings derived from the Baserritik Mundura experience, putting the focus of our analysis on the comprehensiveness of the pedagogical proposal. First, we present the different pedagogical dimensions that cross over in an attempt to create a multidimensional educational environment, seeking to challenge and transform our political subjectivities, our individual and collective practices, and the meanings and relationships that sustain them. From the logic of the systematisation of experiences, we then present how the different pedagogical dimensions are worked, as well as the general and specific learning identified after two editions of the training experience in Euskal Herria, highlighting both the strengths and the shortcomings identified. These outcomes are then discussed, and the conclusions are presented.

\section{Presentation of the Case Study}

The purpose of the Baserritik Mundura training experience was to strengthen different processes and agents that work for agroecology and food sovereignty in Euskal Herria. This pilot experience was jointly organised by the agrarian union EHNE-Bizkaia, the Etxalde peasant movement and Hegoa, the Institute of Development Studies and International Cooperation of the University of the Basque Country (UPV/EHU). EHNE-Bizkaia, as a member organisation of LVC, supports and implements the theoretical and practical training and research in agroecology and food sovereignty as strategic and priority lines of work, and is part of a broader peasant movement called Etxalde. Some members of these peasant organisations and also researchers of the Hegoa Institute had previously developed collaborative relationships both in the field of research and training and had participated in the courses and in the political-pedagogical commissions of the ENFF in Brazil. From these previous experiences, the Basque peasant organisations proposed the need to promote a degree in agroecology in the public university that would contribute, from training and research, to strengthening the networks of organisations working at the centre of food sovereignty in the Basque Country. Thus, EHNE-Bizkaia and the Hegoa Institute decided to combine their abilities and knowledge to carry out a joint research-action process to design and implement this degree.

The phases of the action-research process developed for the design of the pedagogical proposal of the Baserritik Mundura course covered three years (2012-2015) and were as follows: in the first phase (2012-2013), diagnosis mapping and obtaining direct knowledge of training experiences on agroecology and food sovereignty in other contexts was carried 
out; in the second phase (January-May 2014), the initial proposal was drafted, the initiative was publicly presented and contributions were collected; the third phase (June 2014April 2015) was dedicated to incorporating contributions and seeking support for the implementation of the first pilot edition; and in the fourth phase (May-December 2015), the design of the pedagogical proposal was finalised, the work teams (CPP and pedagogical team) were formed and the materials for its implementation were prepared [41,42]. In this design process, it was decided that it should be a university extension degree and not an official postgraduate degree (specialisation degree or university-level expert, master's degree or doctorate), since the limitations implied by the "official nature" compromised the criteria defined as priorities and the coherence of the proposal itself. In this way, greater flexibility was guaranteed in relation to the following: the access requirements of the students, the profiles of the teaching staff, and the pedagogical and organisational method of the course. Thus, both during the design process and in the development of its two editions (2016-2018), these organisations adapted the training model that characterised the training processes of La Via Campesina to the Basque reality. For this purpose, the experience of the ENFF of the MST in Brazil was taken as the main reference, such that the organisational forms and the different political and pedagogical dimensions of the ENFF proposal were incorporated into the cultural and territorial idiosyncrasy of the Basque Country. All the organisational elements of the ENFF proposal were incorporated with the exception of the Children's Ciranda, as it was considered that there was no organisational capacity to facilitate this pedagogical space for the attention and care of the children of the people participating in the course. The experience and conception of the Children's Ciranda in the MST arose from the need to debate about childhood and to work on this issue in the movement's settlements and camps. Subsequently, the Children's Ciranda was incorporated into all education and training activities to facilitate the participation of landless women in courses, congresses and meetings, while working with children from the perspective of the pedagogy of the movement. The ENFF has its own Children's Ciranda.

A change of approach was needed to use the pedagogical knowledge accumulated by ENFF and LVC organisations as a theoretical and methodological reference; a comprehensive and holistic way of understanding training and educational practice was needed. This change in approach brought with it a change in the political-pedagogical perspective that enabled us to deliberate and construct a collective training process from the logic of protagonism and co-governance of all the people who participated in it. It also meant assuming that the methodological is not neutral, that the methodological is political, and that another challenge to be faced was that the training methodology and its training model ought to be consistent with the comprehensive nature of the transformations that the agroecology and food sovereignty approach entails. Therefore, this change of approach led us to understand that the training process that we were beginning to define would be a process in permanent construction, and that in this type of process, all the people involved (students, teaching team, territorial agents) have things to contribute and to receive, learn and teach.

For all these reasons, it was decided to experiment and build a pedagogical proposal that would embrace the integrality of the pedagogical process as a whole, ensuring that all the participants felt as if they were protagonists of it. Baserritik Mundura, therefore, incorporates and adapts to the Basque reality and is less of a specific pedagogical method, but rather a particular and contextualised concretion of certain benchmark principles used to build an educational environment; at Baserritik Mundura, we use the notion of the educational environment of the MST, an organisational methodology that combines different types of activities with ways of functioning, attitudes and being in a collectivity [20,25,44]. The training model proposed by Baserritik Mundura is based on common principles with other LVC training processes, but with others added that are considered necessary given the particularities of the training process itself and the Basque context. Some common principles with other LVC formation processes are: (a) organicity; (b) alternation: university time-community time; (c) the dialogue of knowledge and horizontal exchange of experi- 
ences as primary processes of knowledge construction; (d) that all times and spaces are understood and constructed as formative; (e) praxis is conceived as a transversal pedagogical principle, and entails transforming oneself by transforming; (f) the incorporation of the formative dimension of mysticism; $(\mathrm{g})$ internationalism as a transversal philosophical principle; and $(\mathrm{h})$ the full monitoring of the pedagogical process by a PPC $[10,13,17,41]$. Some particularities that were added given the Basque context included linguistic plurality (Basque and Spanish), the use of Basque (minority language and in the process of recovery) and the transversality of the feminist perspective, as discussed later.

Building an educational environment requires going beyond building a content programme or introducing group dynamics in the methodology of the sessions and visiting agroecological experiences in the territories. It requires work and prior collective planning to pedagogically intentionalise different aspects, such as how to organise the course; the different spaces and times of the training process; the work and coexistence relationships that are generated; and developing the perspective and ability to pedagogically take advantage of the different circumstances and conflicts that arise in the process. All this is reflected in the structure of the course itself, in its pedagogical methodology and in the way it is organised and the groups that bring it to life.

At Baserritik Mundura, we use three methodological tools to build an educational environment: (a) the pedagogical political accompaniment, carried out by a group called pedagogical political coordination (PPC); (b) the collective definition and permanent construction of the pedagogical-political proposal (PPP) where the philosophical, organisational and pedagogical principles that guide the process are made explicit and explained; and (c) the organisation of the training process contemplating different times to work on different educational dimensions. These are three methodological tools used by the ENFF/MST to build an educational environment in its training processes. For further information on how Baserritik Mundura's experience incorporates and adapts these tools, see [42] (Figure 1).

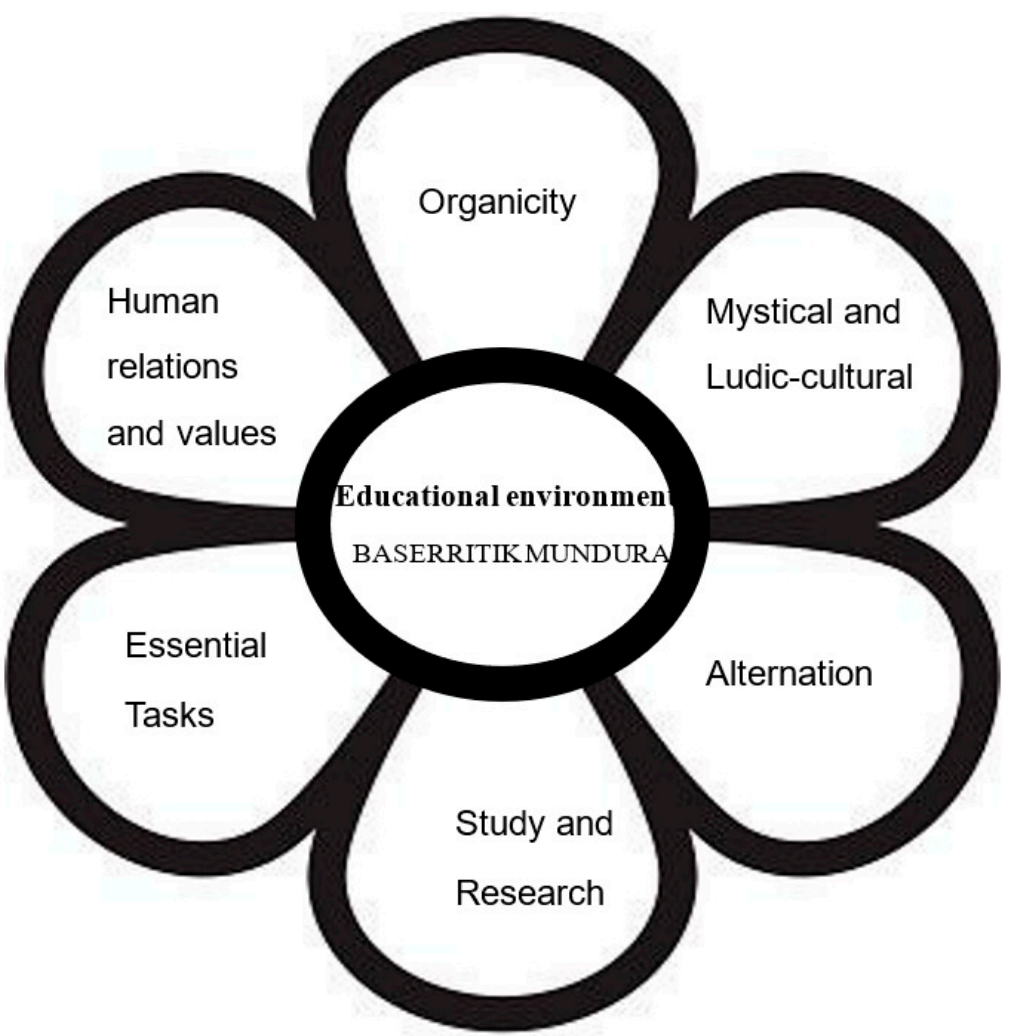

Figure 1. Pedagogical dimensions of the Baserritik Mundura course. Source: Casado [41]. 
Figure 1 represents the pedagogical dimensions of Baserritik Mundura, i.e., how the training process, even though it was itinerant and without a school or a specific physical space, built an educational environment interweaving a set of practices and attitudes that generated a multidimensional pedagogical process. In fact, these dimensions are part of a totality and, therefore, they are dimensions which are interrelated, interwoven with one another and with no hierarchies between them. Together, they all make sense and develop and enhance each other since they are each part of the whole educational process, not separately but systematically. Table 1 presents the specific meaning of these dimensions and their materialisation in the Baserritik Mundura experience.

All these dimensions come from the pedagogical proposal of the ENFF/MST, but the difference in Baserritik Mundura's proposal was in the way in which they were organised methodologically, and according to a situation marked by the particularities, needs and capabilities of the context, the work teams and the training process itself.

Table 1. Pedagogical dimensions and their materialisation in Baserritik Mundura (BM).

\begin{abstract}
Organicity: The definition of collective organisational structures that enable the self-organisation, co-responsibility and co-governance of the training process by all people. These structures are organised in different work groups, providing that the engine of the pedagogical process and the main educating subject is "the collective". It aims to break the unidirectional scheme of knowledge transmission.

In BM: Each student belonged to a territorial nuclei (TN) for the entire course (Figure 2), and at the same time, at each stage, was part of a different work team (coordination, recording and memory, care, ludic-cultural). Additionally, the teaching team was organised into different groups: pedagogical political coordination (PPC), pedagogical couples, research accompaniment team.

Alternation: The development of the course through intensive meetings of coexistence and training, in different accommodations located in different rural areas, and alternated with times of research-action in the communities/organisations. This enables the training process to be dynamic, flexible and unique in each edition. It allows the process to be a permanent construction, with a margin of time between the different coexistence meetings, to incorporate suggestions for improvement, make adjustments to the proposal, or think about and prepare how to pedagogically approach any issue that arises or that the group itself raises [45].

In BM: University times (UT) are intensive meetings involving 4 days of training and coexistence in different rural areas of Euskal Herria, alternated with community times (CT) lasting several months. During the CTs, collective works are proposed to the TNs to deepen the contents of the subjects in a self-organised way, whereas the research studies are developed collectively. During the CTs, the pedagogical couples and the PPC had a space for coordination, collective work and training referred, to as pedagogical seminars.
\end{abstract}

Essential tasks: The organisation of all tasks on a rota basis (manual and intellectual, productive and reproductive) that are necessary to maintain the process, the requirement being that this be organised collectively.

In BM: Productive and reproductive jobs in TNs and work teams, both in university and community time. A total of four work teams were defined: coordination, registration and memory, care and ludic-cultural. These tasks were distributed within each TN, and were rotated at each stage of the course. In this way, all the people of the TN assumed different responsibilities, with the idea that all work is given the same importance whether it be more rational-organisational or more relational-emotional. The work teams also encouraged each student to work collectively and in a self-organised way with people from other TNs.

Mystical and ludic-cultural: Through different languages and forms of expression, the connection between the political and the physical, emotional, cultural, symbolic, identity, and the history of the struggles, etc. was encouraged, promoting the construction of links with rural culture and local people and the history of various struggles and internationalism, nurturing identity and collective cohesion, trust, commitment, closeness, creativity, fun and contentment.

In BM: The aim was to incorporate mysticism through the use of symbolic objects, rituals, artistic performances, celebrations, commemorations, anniversaries, etc., both explicitly in the different work spaces by TNs and the PPC in university and community time, and implicitly in the outlook when working individually and collectively. The aim was to incorporate diverse knowledge, languages, forms of expression and communication without exclusively privileging the word and the text, and combine different modes of learning such as remembering, feeling, the use of body language, creating, theatricalising, dancing and playing. All of this materialised in the following ways: performances and musical fanfares to wake up the group, cultural nights, visits to places full of cultural significance and symbolism in Euskal Herria in relation to the themes worked on, the pedagogical use of poems, songs, drawings and Basque mystical representations prepared by the TNs and the PPC. In addition, as a fundamental part of the process of building the group as a collective subject of learning and action, each class of the course created and adopted its own name (first edition, Piztu da Hazia; and second edition, Besardakada). Similarly, each TN also carried out a process of constructing its identity, developing a name that would reflect its character and reinforce its identity in the face of action, as shown in Figure 2.

Human relations and values: The politicisation of the values on which our relationships are based, as well as the way in which we relate, is also considered a training dimension to work on.

In BM: The alternation system allows values and personal and collective interpellation to be politicised permanently, both in the coexistence of the group in university time, as well as in TNs in community time, both through theoretical and practical contents, as well as through the mystique and the set of tasks needed to develop the pedagogical proposal.

Study and research: This focused on the importance of articulating the different accumulated knowledge (academic, popular, feminist, etc.) and linking them with research in a rigorous way in order to understand what happens in our territorial reality.

In BM: This is developed in the integrality of the pedagogical proposal through the ten subjects of the course, the cross-sectional research subject, the different agroecological experiences visited as part of the training process and the pedagogical seminars organised during the course. In the two editions, nine research studies were carried out by the nine TNs together with the territorial agents involved, under the participatory action research (PAR) model. The research topics were defined by the peasant movement's co-promoter of BM; each TN, together with the agents with whom they were linked in their territory, agreed on one of these research topics based on its relevance and need in that specific territory. 


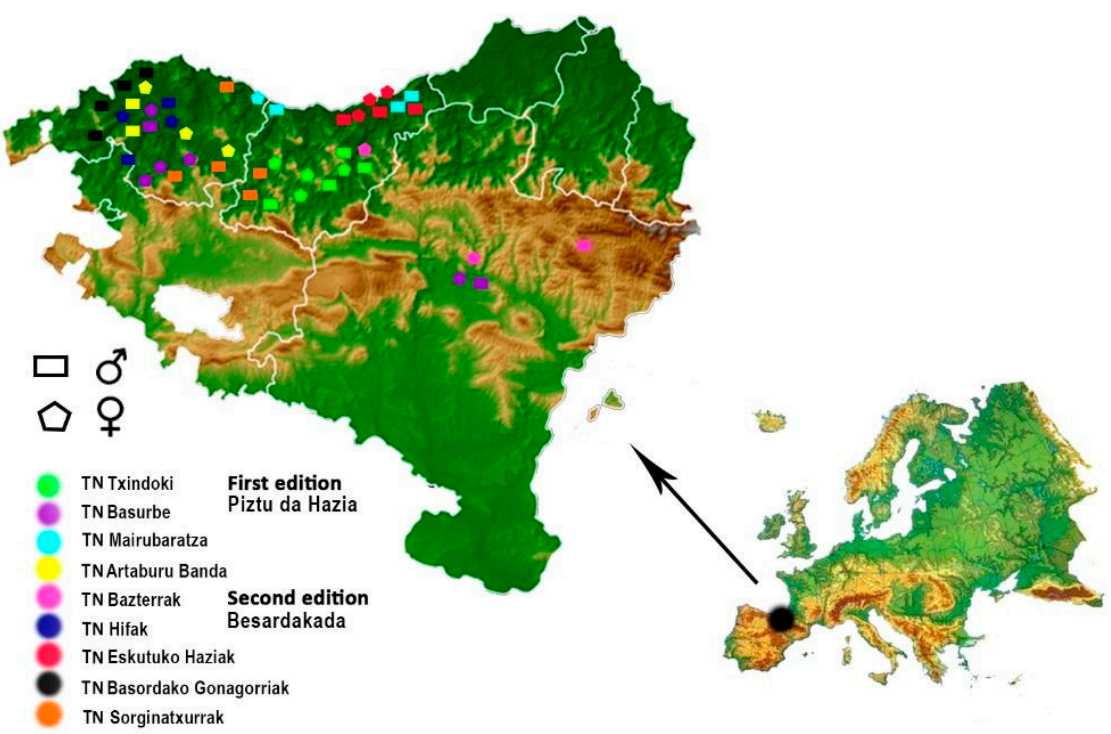

Figure 2. Identity and geographical location of Baserritik Mundura and of the participating territorial nuclei in the two editions.

In the case of the TNs, the aim was to generate the encounter, the dialogue, the exchange of experiences and the development of collective research between people from a territory (valley, region, province) who signed up to the course, and who were already promoting or had an interest in promoting processes of agroecological transition and food sovereignty in different environments. The composition of the TNs in the two editions of the course varied from three to seven people, grouped in consideration of the geographical proximity of residence or place of work and the diversity of gender, age, groups the people belonged to and the areas of action. With regard to the specific profiles of the NTs' components and taking into account the strategy and objectives of the course, a series of priority profiles of people and groups towards whom the training is geared were defined in order to favour, through the training process, the meeting, dialogue and construction of alliances between different processes and subjects in the rural and urban spheres. Thus, diverse groups were configured in relation to different variables, such as: target profiles of the course, previous training, place of residence, militant trajectories and age, and forming heterogeneous TNs but with common interests.

With the intention of visualising the process logic of everything previously developed, in Figure 3, we collect the integrality of the Baserritik Mundura process:

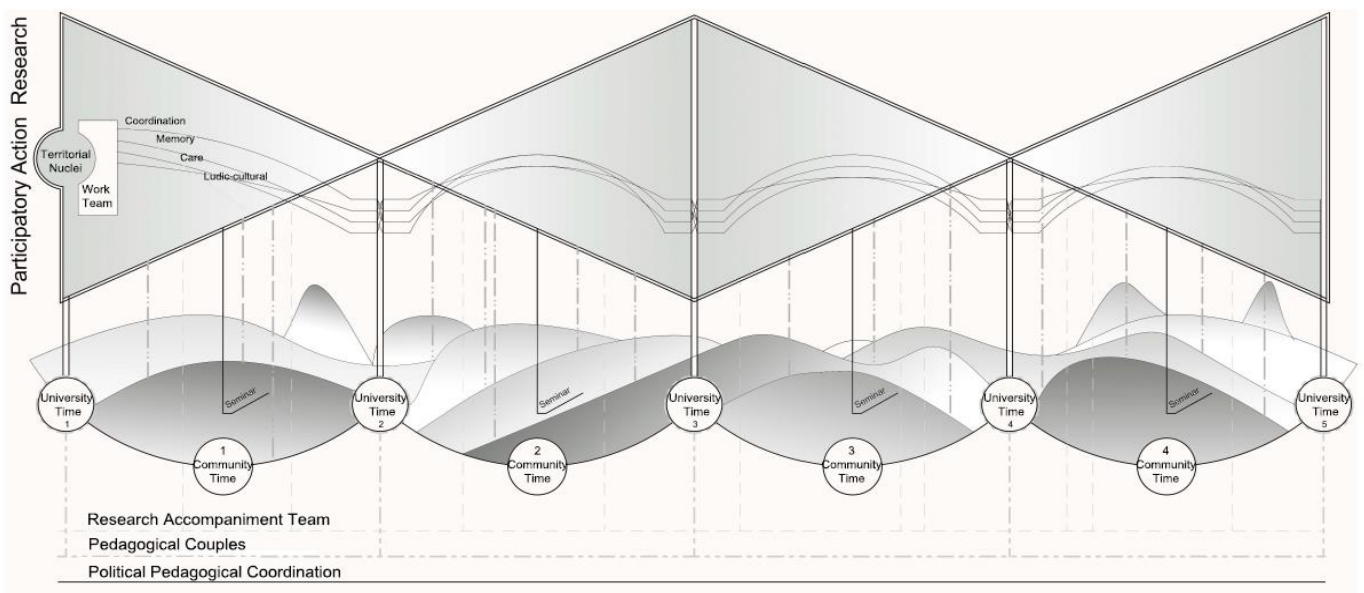

Figure 3. The integral process of Baserritik Mundura. 
Finally, Table 2 lists the research carried out by the TNs of Baserritik Mundura in its two editions as a reflection of the direct contribution of participatory action research processes in the territories. These studies were socialised during the course in university spaces through different activities. Some TNs even managed to involve the actors who had participated in the processes in the presentation of the research.

Table 2. Titles of the research carried out by the TNs.

\begin{tabular}{ll}
\hline Baserritik Mundura 2016. Piztu da Hazia! \\
\hline "Limits and opportunities for the marketing of local agroecological \\
produce in the hotel and catering trade, small shops, squares and \\
consumers" in Bizkaia and Nafarroa
\end{tabular}

\section{Methodology}

The methodology used for the analysis of the Baserritik Mundura experience is the systematisation of processes. The notion of systematisation of experiences arises as a critical interpretation of one or several experiences that, based on their ordering and reconstruction, explains the logic and meaning of the process lived through the experience: the various factors that intervened, how they related to each other and why they did so in a certain way. Through systematisation, significant knowledge is revealed that makes it possible to critically own the experiences (their knowledge and feelings), extract learning, understand them and improve on them in the future, both in pedagogical experiences [46-50] and in experiences related to food strategies with an agroecological perspective [51].

As required by the methodology, a systematisation axis is adopted, which in this case, is the pedagogical methodology defined in the training process, and which is built throughout the experience. The main objectives of Baserritik Mundura's systematisation process are: (1) to ensure the systematisation process itself is pedagogical and promotes the construction of collective knowledge; (2) to value and make visible the knowledge of the people and groups that have been its protagonists; (3) to analyse the experience by identifying learning, limitations and challenges from different perspectives and points of view; (4) to critically own the experience to improve it during its development and understand it with greater complexity; and (5) to promote Baserritik Mundura as a proposal for innovative pedagogical and organisational experimentation, built collectively by bringing together multiple efforts. Therefore, systematisation aims to identify the key elements that the pedagogical methodology defined in the political training processes must bring 
together in order to respond to the challenges of generating and expanding training and research spaces for food sovereignty within the university remit.

In addition, from the outset, the evaluation and systematisation of the experience itself is built into the training dimensions. For this, a process evaluation plan for the course is designed to address three considerations: to evaluate the individual and collective performance of the students, as well as the research processes developed; to evaluate the usefulness of the process of systematising the experience in its first editions; and to check it is consistent with the course proposal itself, ensuring that all the participants are included and heard. In this way, each person completes a self-evaluation and, in turn, evaluates and is evaluated by the rest of the participants and the process overall, thereby contributing, through evaluation, to individual, collective and process growth.

Information gathering was a process developed throughout the two editions of the course by generating different activities, spaces and moments to collect reflections, evaluations and learning around this axis of systematisation, from the different perspectives of its protagonists (students, teachers and PPC). To facilitate this reflection, a timeline was drawn up during the last intensive meeting on the university time of each edition of the course to reflect the lived experience, the factors that had influenced it and how it was carried out. This chronological reconstruction allowed for the recollection of what was experienced throughout the course to be able to reach a collective reflection on the experience.

The primary sources of information used were: (1) records of individual and collective evaluations carried out after each stage of both editions of the course by students, teachers and the PPC; (2) records produced during the last face-to-face meeting of each of the editions, where different specific exercises are carried out with each group of students to evaluate the methodology and identify learning; (3) four group interviews carried out with the students of the first edition where they reflect and analyse the lived experience; (4) records of the exercises and debates carried out by the PPC in the evaluation and systematisation sessions after the end of each edition; and (5) records of the evaluations and discussions of the accompaniment-research team during the second edition. Moreover, the doctoral thesis of the coordinator of the systematisation process was used as a secondary source [41].

From the outset, all the participants were informed of the objective of the systematisation and of our role. The participants were informed we had a role in: (1) facilitating the dynamics and source documents for the development of the systematisation; (2) being responsible for recording the information generated throughout the process; and (3) being responsible for analysing the results and returning them for a final collective assessment. Thus, to close the process, a session was held to report back to the group of participants on the systematisation after the completion of the two editions. In addition to this role in the systematization process, the undersigned persons participate in the course as part of the teaching team and the political-pedagogical accompaniment and also, to a greater or lesser extent, of the CPP. Depending on the case study, we have a greater or lesser formal link with the university from our hybrid role of being part of social movements and popular initiatives.

\section{Results of the Systematisation Process of the Experience}

In this section we present the results generated through systematising the experience, based on eight main themes, taking into account not only the pedagogical and political dimensions of the course that have been explained, but also those themes that came out most frequently in the systematisation experience of BM. We begin with those aspects that are more related to the pedagogical and political dimensions explained, such as organicity, alternation and the mystical and ludic-cultural dimension. We then address learning related to the contents, subjects and the teaching team, as well as the proposal as a whole and its perspective of popular education and action research. We finish by specifically addressing the transversality of the feminist perspective, linguistic plurality and the pedagogical political accompaniment of the process. Through these eight themes, this section presents 
the successes, shortfalls, learnings and limitations of the specific experience. Following on from this, the discussion section presents the considerations and general proposals to be applied to training proposals of this type.

\subsection{Learnings Related to Organicity}

The organicity of the proposal is key for the participants as it allows them to experience a referential organisational functioning model and review the previously known modes of organisation and organisational cultures. Three aspects of learning are particularly valued. Firstly, the territorial organisation of students in territorial nuclei (TN) is highly valued, especially for promoting collective political research and training, and has an impact on the territory by generating links beyond the course and ultimately providing coherence and comprehensiveness to the training proposal. Aspects for improvement refer to the size of the TNs and the criteria when establishing them. On the one hand, the largest and more geographically dispersed TNs show difficulties in reconciling workload, setting up meetings during CTs, working collectively, building consensus, managing conflicts, etc. An optimal size for TNs is suggested as being between four and six people (which was not always possible due to the configuration of the groups themselves based on the reality of the participants). On the other hand, certain criteria are proposed beyond the territorial criterion when considering the constitution of the groups, such as the gender criterion or the linguistic criterion. With regard to the linguistic criterion, proposals include configuring the $\mathrm{TN}$ according to the language in which it is going to work, to anticipating the situations and managing them according to the linguistic diversity of each TN.

Additionally, the organisation of students into four work teams (coordination, registration and memory, care, and ludic-cultural groups) is considered key to promoting the interrelation with people from other TNs, guaranteeing the self-management, responsibility, distribution and rotation of tasks for the benefit of the collective, thus balancing power relations and giving equal value to the different tasks necessary for the operation of the proposal (manual, intellectual, emotional, etc.). An aspect for improvement was identified in the first edition where a certain weakness was detected in the activation of the work teams. This was improved in the second edition, giving the same importance to TN and work teams from the beginning and taking the opportunity during university time to encourage them and discuss the tasks completed in the plenary session.

A third positively valued aspect in terms of organicity is the proximity of the teaching team and the PPC in guiding and politicising collective learning and the process as a whole. Two areas that would benefit from further support are the work teams, reinforcing the orientations and starting tasks for each team, and the PPC in recognising the time that participation demands in order to sustain the process.

\subsection{Learning Related to Alternation}

Alternation between university time (UT) and community time (CT) is considered a key element in the structure of the course. The CTs facilitate the participation of rural people, by being present and listening to the peasant movement in the territory, learning from their experiences, identifying needs, etc. This has contributed to a more rural and grounded character to the training process. In addition, the fact that the course is carried out in an itinerant way through the territory, in different rural places of the Basque geography where there are different contexts and experiences linked to the themes that are being worked on, makes for a better understanding of the diversity of our territory. There is, however, room for improvement when planning logistics and content programming for certain experiences (visits, talks, round tables, etc.).

The UTs are highly valued, although their work dynamics are considered very intense, sometimes excessively overloaded by wanting to develop too many activities and initiatives. The need to guarantee more moments of personal worktime, rest and tranquility is stressed. Among the activities carried out on the university campuses, the conferences organised to present the action-research processes together with the social agents and peasants involved 
in them are all valued positively. These returns and presentations give exposure to other sources of knowledge at the university, and the topics they work on and their contributions in terms of knowledge and practical experience.

\subsection{Learning Related to the Mystical and Ludic-Cultural Dimension}

As indicated, one of the work teams was in charge of the mystical and ludic-cultural dimension, which transpired to be one of the most impressive and best valued aspects of the course due to its power and novelty in incorporating different languages, knowledge and ways of expression and communication. Aspects that could diminish its pedagogical and political potential are the intensive work required during the UT and a kind of mechanisation and theatricalisation instead of functioning as an element of permanent resonance of how the group works or feels while in training during the process. In addition, in the PPC itself, a certain dependence and overload was detected in people who, due to their work history and skills, knew how to work and politicise these dimensions with the group.

\subsection{Learning Related to the Contents, the Subjects and the Teaching Team}

The organisation of the course contents into thematic blocks is viewed very positively, since the subjects are staggered by stages, as well as the fact that the student group is itself an educational constructor of the training process in which it participates. As a result, some of the changes incorporated at the request of the students between the first and second editions were to: (a) reinforce the agricultural contents, giving them more weight and including more people from the agricultural sector; (b) include a subject on peasant feminism involving a feminist group in its revitalisation (see Section 4.6); and (c) reinforce current content linked to their research (forest management model, fishing from an agroecological perspective, etc.). In addition, in the first edition, a certain weakness or limitation was identified in relation to the study, i.e., the appropriation and deepening of the course contents, so in the second edition, the support offered in self-directed training during CT was reinforced. An aspect that requires improvement in both editions is the weak integration of content related to Basque rural and popular culture.

The organisation of the teaching staff into pedagogical couples is valued as a success in complementing views, styles, trajectories, genders and languages and, ultimately, increasing the coherence of the course proposal. Nevertheless, in the first edition it was found that not all pedagogical couples had the same level of involvement, affinity or ease of working together, so in the second edition changes were introduced not only to the composition of the couples, but also in the recognition of different styles, giving couples more autonomy to define their way of working.

In turn, the pedagogical seminars are positively valued as spaces for coordination, collective work and training for teachers in methodologies and perspectives of training and research. However, difficulties have been identified in getting some pedagogical couples to participate in the seminars and get involved in the process beyond their subject. In the first edition, aspects for improvement were also identified, among them: (a) defining at the beginning of the process the availability and commitment to participate; (b) jointly defining how to organise the seminars so that they are useful for pedagogical couples and what topics to cover; and (c) improving coordination between pedagogical couples of the same stage, etc.

\subsection{Learning Related to the Proposal as a Whole and Its Popular Educational Perspective and Action Research}

The proposal as a whole, that of a comprehensive educational environment that generates coexistence among all the participating people through organising, working, interacting, supporting, having fun, sharing tasks and responsibilities, is identified as a very positive aspect. In addition, the course fosters greater awareness about the situation of the agri-food sector in Euskal Herria, not only within the course but also outside of it, since it gives visibility and recognition to a wide diversity of agents and initiatives that 
work in the realms of food sovereignty in the country. The downside of the proposal is the high personal impact it generates, which can lead to frustrations when it comes to sharing and applying the lessons learned in work, family, consumer scenarios and militant spaces, etc. This can be challenging as it involves questioning logics and inertias that are well established. In a way, the course may leave the participants with a certain sensation of being in a "bubble", i.e., removed from the outside world.

With regard to the popular education and action research approach that underpins the course, participants highly value the critical reflection on their own practices and existing experiences in the environment since it makes them feel recognised as subjects of knowledge and collective creators of it. This perspective of popular education, combined with the heterogeneity of the group of participants (profiles, organisations, experiences, ages, etc.), greatly enriches the pedagogical process. Similarly, the encouragement of a critical review of both the contents of the course and its methodology is highly valued, not only of the agri-food system but also of political culture, the ways of organising the group, making decisions, interacting, articulating, managing differences, conflicts, etc.

However, the balance of the action research processes that were generated in the course showed positive and negative aspects. On the one hand, the fact that the research model is based on collective processes developed by each TN in terms of collaborative social intervention with agents of the territory is highly valued, which is unusual in the university environment. On the other hand, it was deemed that the necessary conditions do not exist to carry out action research processes with sufficient depth, neither for the investigation teams nor for the expert and qualified accompaniment. For this reason, it is recommended that the action research processes are simplified and adjusted to the time of the course, as well as to more specific research and advocacy needs in order to strengthen the peasant movement at the local and regional level. In this way, the contributions of the course would be more relevant in terms of research and community action.

\subsection{Learnings Related to the Mainstreaming of the Feminist Perspective}

The mainstreaming effort with regard to the feminist perspective is valued through elements such as (a) seeking gender balance in pedagogical couples; (b) prioritising participation in the feminist movement to select both teachers and students; (c) urging the teaching team to include the feminist perspective in the different sessions and didactic guides, not only in content but also in references and materials; (d) including a research axis on peasant feminism; (e) carrying out gender observations in different spaces of collective work; and (f) including support both in TN and in work teams to encourage debate in this regard.

In the first edition, this perspective was considered present but lacked clarity so, in the second edition, two important changes were made. On the one hand, pedagogical couples were asked to improve the incorporation of the feminist perspective in courses and didactic guides. In this way, progress was made in the incorporation of inclusive language and in overcoming a neutral and productivist discourse that renders the reality of women invisible so that the caring and reproductive work is taken into account, as well as the specific consequences that exist for them concerning the analyses presented, among other issues. On the other hand, as already discussed, both a specific subject on peasant feminism and an open seminar on peasant feminism were included, involving a collective linking agroecology and feminism in its dynamization. In this way, FCP's inclusion was more transparent in the process, not only in the mystical and ludic-cultural dimension, but also by including the process of building the FCP in LVC in the subject of peasant feminism. In addition, the construction of the peasant feminism guide was an unprecedented reflection that considered the relationship between feminist economics and the food chain, reaching such interesting proposals such as that of the iceberg of the food chain, which have since been used and referenced in various analyses [52-54] (Figure 4). 


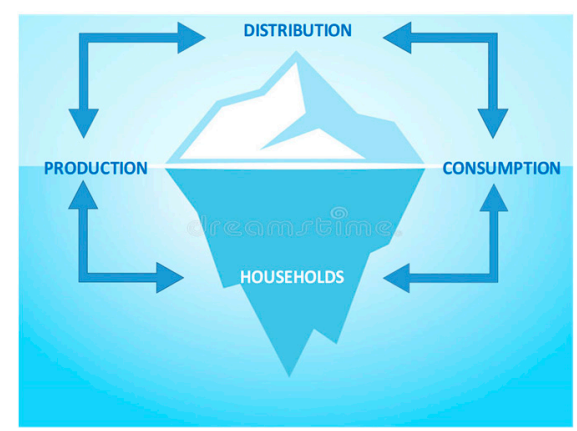

Figure 4. The iceberg of the food chain. Source: Urretabizkaia and Arroyo [52,54].

Following these changes, the evaluations of the second edition reflect a solid and continuous presence of the feminist debate, not only in the subjects covered but also in mysticism, the internal dynamics of the TN and in several of the research studies. Aspects for improvement in both editions include: (a) a weakness and lack of a feminist perspective in some subjects and didactic guides; (b) a weakness in the way of working with the incorporation of the feminist perspective through the support team; and (c) the need to carry out gender observation in some spaces and give feedback in plenary sessions.

\subsection{Learning Related to Linguistic Plurality}

The coexistence of two languages and the efforts made to guarantee a dignified and significant presence of the minority language, Basque, in all areas of the course (such as the translation of all materials and didactic guides into Basque; subjects taught only in Basque and with simultaneous translation; bilingual talks and round tables, etc.) are aspects that are valued positively and highlighted as differentiating and innovative aspects in relation to other bilingual training processes (university and non-university) carried out in Euskal Herria. Despite this, the translation of many course documents and teaching guides from Spanish to Basque still showed room for improvement, even when carried out by professionals. Considering the possibility that the didactic guides for the subjects are written first in Basque and then translated into Spanish could have guaranteed that there would be content designed and written in both languages. In any case, the translation of materials is not considered sufficient to carry out a non-asymmetric approach to languages. In fact, at the level of the internal organisational process, the work dynamics of the PPC (and of most of the organisation as a whole) in its meetings, debates, reflections, preparation of materials, etc. has not managed to be bilingual, nor to give a significant presence to the minority language. In addition, and as we have already seen, in the configuration of the $\mathrm{TN}$, there were different positions regarding the linguistic criterion proposed for its configuration, from configuring the TN according to the language to be used to anticipating the situations and managing them in relation to the linguistic diversity of each TN.

Thus, it was precisely the group of participants themselves who, in the second edition of the course, identified these limits and raised these criticisms on the linguistic issue. In the pedagogical philosophy of addressing criticism and conflicts as a pedagogical opportunity to deepen the emancipatory nature of the training process, the PPC proposed carrying out, together with the group of participants as a whole, a process of reflection, self-criticism and transformative practical proposals of our linguistic practices. It should be noted that carrying out this process collectively contributed to approaching the debate in a pedagogical way, from both a linguistic and a political point of view, providing multiple lessons for the PPC and for the group as a whole. As a result of this process, in addition to generating a debate and more politically conscious linguistic practices, a framework document of the language policy of the course was drawn up where reflections and proposals for improvement were collected. 


\subsection{Learning Related to the Pedagogical Political Accompaniment of the Process}

The political pedagogical accompaniment of the PPC and the CT support team is valued as essential for the development of the training process, highlighting the flexibility and capacity that the PPC had in both editions to articulate and guide the process. The following attributes were deemed necessary to achieve this: the maintenance of an intense continuous dynamic of collective work; a high level of enthusiasm, emotional involvement and political commitment to the proposal; flexibility and ability to adapt to changes; and the complementarity of profiles, perspectives and communication styles of the people who were part of it. Particularly valued was the accompaniment of the CTs of the second edition which served to incorporate students from the first edition and thus give continuity to their involvement with the process, even though these incorporations implied a high degree of responsibility and more training in action research and the monitoring of processes. In addition, the way in which conflictive issues that arose in the process were handled in the group was highly valued, such as the debate on the linguistic issue and the fact that the second edition of Baserritik Mundura was to be the last, with no continuity of the training proposal.

To understand why the course was not continued, it is important to take into account the difficulties of the agrarian organisations in promoting the proposal to participate in the PPC on a continuous basis, beyond the person hired for it. Initially, it was difficult to adequately specify and gauge the workload or the availability of time and energy that a training process of these characteristics would require. Some of the people with responsibilities in sustaining the process were not familiar with the approach and the pedagogical-organisational methodology of the course, and dedicating time to carrying out training prior to or during the process was not possible. Furthermore, only two people from the PPC were partially paid and, therefore, the majority of people supported the process from their commitment as activists within a new and diverse team whose composition varied from one edition to another. This finally generated different ways of understanding the proposal at the political and pedagogical level in the organisations driving change and in the PPC. These different positions taken towards the proposal were divergent, which led to the organisations deciding not to continue with the initiative.

\section{Discussion}

In the previous section we presented the results of the Baserritik Mundura systematisation process that enabled us to analyse the learning derived from this training experience which adapted the pedagogical references of the ENFF and Latin American agroecological schools to the European and Basque context. Based on these learnings, this section presents some considerations to bear in mind when developing courses and training in the field of agroecology, with the focus of discussion being on two aspects:

- The change needed in epistemological and pedagogical perspectives to give the training processes an integral, experiential and emancipating character.

- The strategic nature of training in order to strengthen agents and processes in terms of agroecology and food sovereignty in the general context of the commercialisation and corporatisation of universities and their offered training.

Through these two focuses, we discuss ways of rethinking and redesigning training processes in order to generate transformative and emancipatory practices. The objective is that these processes encompass different pedagogical dimensions that, in an intertwined way, create an educational environment and a life experience that transforms our personal and collective practices, and the imaginaries, senses and relationships that sustain them. Ultimately, it is about transforming training processes into meaningful experiences of collective organisation, mutual learning and the collective creation of knowledge and transformative practices.

The first aspect, that of the change of epistemological and pedagogical perspective to give the training processes an integral and emancipatory character, highlights some 
of the more significant pedagogical elements that could be applied to other ongoing training experiences.

Firstly, we consider the participative nature of these peasant training models, developed through group organisation and with the intention of learning something from all the tasks that arise from the training process. This organicity means that the process generates a diversity of tasks and responsibilities to be carried out in different work groups, of an intense nature and with significant impact on the individuals and the group. It facilitates a high level of appropriation and internalisation of the training process and contributes to a greater awareness of the potentialities and difficulties of working collectively. Specifically, it builds awareness of how we reproduce in everyday life what we want to transform, identifying the inertias and contradictions that arise and, through politicising the process, learn to transform them. We learn that the organisational and pedagogical methodology that these types of experiences are based on challenges us and makes us more aware of personal and collective contradictions and the extent to which these capitalist/corporate, colonial and patriarchal logics and values run through us and how we reproduce them in our daily spaces. Furthermore, in working towards the dynamics of mutual learning, trust and support, these experiences are privileged spaces for identifying hegemonic inertias and experimenting with ways to overcome them, and generating enthusiasm and motivation for the ongoing task of the personal, organisational and structural transformation of our societies.

One element of learning and discussion highlighted is the necessary capacity of the PPC to focus and work pedagogically on the worries, concerns or unforeseen events that arise in the group during the training process, trying to politicise the learning process as the course develops, as well as incorporating the questions and proposals for improvement that the participants suggest. In this particular case study, we highlight the learning that was generated from the group's questions regarding linguistic plurality and the use of Basque. The course established certain moments and spaces for the minority language in some subjects and activities, with significant attention to simultaneous translation and the translation of materials to make the presence of both languages visible. However, the group questioned the fact that the course was designed, managed and guided in the dominant language (Spanish) and that the development of teaching materials and handbooks in Basque was not guaranteed neither was the ability of the PPC to carry out its task of thinking and guiding the training process using the minority language (Basque) as a working language. This questioning, the debate that it generated, and the tools agreed on to recognise and mitigate the limitations and contradictions that the course had in terms of linguistic plurality made for a rich political and pedagogical learning experience both for the PPC and for all the people who participated in the course.

Secondly, we consider as fundamental the aspect of the mystical and ludic-cultural dimension in its application to other experiences due to its importance in: (1) working on the construction of identity and the cohesion of the TN and the group as a whole; (2) connecting the political with the emotional, the physical and the symbolic; (3) encouraging commitment, complicity, creativity and joy; and (4) strengthening ties with local, rural and popular culture, the history of various struggles, internationalism and the connection between resistance, etc. In fact, given its value and impact, greater importance and dedication should be given to this type of activity. In the experience analysed in this paper, systematisation highlighted the need to dedicate more time to this aspect, both in UT and in $\mathrm{CT}$, to reconstruct memory, collect materials and prepare proposals. Ideally, several people should be specifically responsible for preparing and working with the group and with the PPC on this important political-pedagogical dimension.

A third pedagogically relevant aspect is the use of group dynamics, games and participatory ways of working. These dynamics promote group cohesion and complicity, and generate participatory work dynamics for the individual and group empowerment of people with diverse life experiences and knowledge. These are group dynamics and ways of working that seek to guarantee equal participation and a collective construction 
of diagnoses and proposals that emerge from the different daily experiences of the people who participate in the process. This is focused on overcoming the one-way transmission of knowledge and moving towards the group creation of knowledge. In other words, rather than being simply a pedagogical method and participatory dynamics, this is a way of understanding the creation of knowledge horizontally and collectively, at the service of processes of emancipatory empowerment and collective organisation.

Lastly, these experiences affirm that it is possible, although also complex, to build training and research processes that are based on the encounter, complementarity and horizontal collaboration between different epistemic and pedagogical subjects (academic groups and social-popular organisations). In other words, from a dialectical work logic, it concerns the bringing together of different capacities and knowledge to generate a more complex and diverse synthesis, which gives depth to the training process both in terms of content and form (peasant language and code, academic, artistic etc.). However, this dialogue and joint construction is not without tensions when confronting different logics, ways and codes of working on the issues addressed. For example, if we take into account the need to mainstream the feminist perspective, different challenges arise in the organisation and pedagogical support, the teaching team and the role of the organisations promoting the course. In this sense, these types of collaborations and joint processes between different organisations and institutions reveal discrepancies and tensions of a diverse nature.

On the one hand, they reflect the high level of political commitment, personal involvement and dedication required for training proposals of these characteristics. The systematisation of this experience shows the need to create the necessary conditions so that those who participate (both organisations and participants) can dedicate the time and energy necessary for the development of the training process, thus avoiding frustrations derived from the demands of the course. This calls for laying solid foundations for the sustainability of the course, understanding sustainability from a broader point of view which goes beyond the economic to encompass the political, the pedagogical and the emotional and progressing in a more considered way with greater consensus.

On the other hand, tools are needed that can identify, understand and adequately manage this diversity and the tensions and conflicts that it can generate, something that was not satisfactorily achieved in the experience analysed. For example, some NT had problems of communication, organisation and internal dynamization, some students and teachers were not involved in the way that the proposal expected them to be, which increased the distance and discomfort between the different profiles of involvement. There were also asymmetric power relations in the CCP and in other group processes of the course. This led us to identify certain errors or learnings, and to make the following recommendations: ensure the operation and decision-making mechanisms of the PPC and the organisations promoting the course are clearer; improve the management of disagreements and tensions in terms of listening, self-criticism and mutual support; and introduce or ask for guidance from people who, through their role of facilitating groups and processes, can help address any tensions in a constructive way. In fact, the systematisation of this experience suggests the incorporation of tools, such as nonviolent communication [55] and group facilitation sessions, to work on issues both internal to the functioning of the TNs and to the PPC itself and the relations with the different promoter agents and organisations. Thus, from a processing logic and in coherence with feminist practices, we should be alert to the reproduction of asymmetric power relations, heteropatriarchal dynamics, colonialisms, etc. It is, therefore, very important to include an intersectional perspective that takes into account how oppressions and privileges intersect both in the groups that make up the training experiences, as well as in the political framework of the experiences of food sovereignty and agroecology. We consider this to be an area that needs further attention [38].

All these findings lead us to the second focus of discussion, which is the strategic nature of training in order to strengthen agents and processes in terms of agroecology and food sovereignty in the general context of the commercialisation and corporatisation of universities and the training they offer. We look at this from three main perspectives: 
(a) private companies have an increasing presence in the management of university services; (b) the university itself reproduces meritocratic, corporate and technocratic culture and logic in its way of functioning, and responds more and more to the research and training needs and demands of the capitalist market and corporate power; and (c) public universities are putting aside, even in many cases abandoning, their social and critical role, an issue that is reflected in the decline in dialogue and collaboration with social agents to build knowledge and processes for innovation in terms of emancipatory social transformations. Thus, the official educational system, under educational models and with pedagogical methodologies that are unidirectional, individualising and meritocratic, offers a fragmented and fragmentary training that hierarchises, neglects and divides different educational dimensions. This reinforces the reproduction of hegemonic ideologies and logics, and the dominant economic, political and agri-food models without allowing the critical questioning of them.

The agroecological training experiences that are taken as a reference in this paper represent an attempt to transform the organisational, pedagogical and epistemological logic of the postgraduate courses that are developed in most public universities. They are, with their successes and shortfalls, experiences of critical and popular training that give recognition to peasant knowledge and aim to transform the university and public educational system as a whole into a space for the construction and transmission of emancipatory knowledge and practices. Within this framework, one important aspect we have discovered in experiences such as the one presented in this paper is that pedagogically, the main driver of the educational development of the participants is the group itself, including its organisation and its daily relationship dynamics, operation and tasks. For this reason, any training thought of as other (built from other epistemological, pedagogical and organisational models) becomes a strategic activity to confront the ideological infiltration of corporate capitalism and its dominance of mentalities and imaginaries.

\section{Conclusions}

According to its participants, the pedagogical practices in the training process that Baserritik Mundura underwent helped to experience, prefigure and put into practice the type of processes and transformations (personal, group and community) that the political proposal of agroecology and food sovereignty requires. An example of this is that the training process generated lasting interpersonal links and continuous mutual support between agents and initiatives who promote agroecological projects to regain food sovereignty. This leads us to conclude that the strengthening of agroecology and food sovereignty requires comprehensive training processes that cross and politicise multiple dimensions of our lives. This implies a change in the political-pedagogical perspective by rethinking and redesigning conventional training courses to turn them into collective organisational processes, as well as the collective construction of learning and politically significant life experiences.

Pedagogical models of this type of training experience are experientially transformative because they interconnect different aspects and contents of our lives (theoretical, practical, organisational and experiential), also linking them to the needs and problems of the territory we inhabit. This calls for training processes capable of combining the theoretical and historical analysis of the social and political phenomena around us, with different types of knowledge, work codes and expressions related to the organisational approach, the group, affections, physical needs, rituals, artistic values, etc.

In fact, one of the intuitions derived from the case study is that this type of process, where the training proposals generate self-organisation, collectively shared work and intense experiences within politically reflected group coexistence, results in a connection of ideas, physicality and emotion. This has the enormous potential to leave a permanent impression on the participants and to give meaning to and reinforce collective political work.

Finally, there remain two important issues for this paper to address. Firstly, the need to strengthen the links between feminism and agroecology at a theoretical, discursive, 
formative and political level is crucial. In training processes, this implies keeping in mind the necessary participation of peasant women and the fostering of a connection between urban and peasant feminism. For agroecology as a movement, science and set of agricultural practices, it implies drawing attention to patriarchal inequalities to consider gender a relevant category, and acknowledging women's own contribution to the movement and to the construction of agroecological knowledge. In both cases, strengthening the links between agroecology and feminism implies, in addition to including the gender category, being able to transcend the categorical logic that leads to prioritising some inequalities over others so as to continue developing an interrelated view of the inequalities that feminism exposes.

Secondly, the global pandemic experienced in the period of 2019-2021 poses serious challenges in the field of education. Fear, isolation, punitive control and the weakening of social and political interaction has exposed us to a period in which discipline and the requirement of obedience for public health issues has been at the cost of proactive criticism and has made it difficult for alternative or nonconformist collective experiences to be developed.

Moreover, with the growth of virtual educational proposals and online training, the universal right to education may suffer due to discrimination through the digital divide and living conditions, with a clear danger of increasing the elitism of education and thus, accentuating class and colonial differences. From the pedagogical point of view, virtual education could also reinforce the distance between the teaching figure as the protagonist who controls the knowledge, and the individualised, passive and merely receptive students. This vertical gap between those who apparently know everything and those who supposedly know nothing implies a persistent naturalisation of asymmetric power relations.

The appreciable challenge of promoting communal training processes to build group and organisational links calls for the need to continue creating and reinventing training processes based on the legacy of popular and peasant pedagogies.

Author Contributions: Writing - review and editing, B.C., L.U., M.B.-Z. and Z.M. All authors have read and agreed to the published version of the manuscript.

Funding: This research received no external funding. The research group Parte Hartuz of the University of the Basque Country (UPV/EHU) provided financial support for the publication of this article.

Institutional Review Board Statement: Not applicable, the study did not require ethical approval.

Informed Consent Statement: Not applicable.

Data Availability Statement: The study didn't report any data.

Acknowledgments: We acknowledge all those who have participated, in one way or another, in the Baserritik Mundura process; the research group Parte Hartuz of the University of the Basque Country (UPV/EHU) for their financial help in publishing this study; Aintzira Oñederra, for the graphic collaboration; and Berta Malvárez and Koldo Telleria, for their involvement and all their contributions in the review. Mila esker guztioi.

Conflicts of Interest: The authors declare no conflict of interest.

\section{References}

1. La Vía Campesina, LVC. Policy Documents. 2009. Available online: https://viacampesina.org/en/la-via-campesina-policydocuments / (accessed on 10 September 2021).

2. McMichael, P. Regimenes Alimentarios y Cuestiones Agrarias; Icaria: Barcelona, Spain, 2015.

3. Van Der Ploeg, J.D. Nuevos Campesinos: Campesinos e Imperios Alimentarios; Icaria: Barcelona, Spain, 2010.

4. Korol, C. La educación popular en la batalla contra las muchas colonizaciones. In Resistencias Populares a La Recolonización Del Continente; Korol, C., Ed.; América Libre: Buenos Aires, Argentina, 2010; pp. 345-358. 
5. Grupo, ETC. Campo Jurásico: Syngenta, Dupont, Monsanto. La Guerra de los Dinosaurios del Agronegocio. Cuaderno n 115. 2015. Available online: http:/ / www.etcgroup.org/sites/www.etcgroup.org/files/files/etc_breakbad_esp_v5-final_may11-2016.pdf (accessed on 8 June 2021).

6. Borras, S. La Vía Campesina. Un Movimiento en Movimiento; TNI Briefing Series; Transnational Institute: Amsterdam, The Netherlands, 2004; p. 6.

7. Desmarais, A.A. La Vía Campesina. La Globalización y el Poder del Campesinado; Editorial Popular: Madrid, Spain, 2007.

8. Martinez-Torres, M.E.; Rosset, P.M. La Vía Campesina: The birth and evolution of a transnational social movement. J. Peasant Stud. 2010, 37, 149-175. [CrossRef]

9. Martínez-Torres, M.E.; Rosset, P.M. Diálogo de saberes in La Vía Campesina: Food sovereignty and agroecology. J. Peasant Stud. 2014, 41, 979-997. [CrossRef]

10. Rosset, P.M. Epistemes Rurales y La Formación Agroecológica En LA Vía Campesina. Rev. Cienc. Tecnol. Soc. 2015, 2, 8-16.

11. La Vía Campesina, LVC. Declaración de Maputo. 2008. Available online: https://viacampesina.org/es/declaracie-maputo-vconferencia-internacional-de-la-vcampesina/ (accessed on 8 June 2021).

12. La Vía Campesina, LVC. De Maputo a Yakarta: 5 años de Agroecología en La Vía Campesina. 2013. Available online: https: / / viacampesina.org/es/wp-content/uploads/sites/3/2013/07/De-Maputo-a-Yakarta-ES-web.pdf (accessed on 8 June 2021).

13. La Vía Campesina, LVC. Agroecología Campesina por la Soberanía Alimentaria y la Madre Tierra. Experiencias de LVC. Cuaderno de Formación n ${ }^{\circ}$ 7. 2015. Available online: https://viacampesina.org/es/wp-content/uploads/sites/3/2015/11/CUADERNO\% 207\%20LVC\%20ESPANOL.compressed.pdf (accessed on 8 June 2021).

14. La Vía Campesina, LVC. Declaración de Marabá. Conferencia Internacional de Reforma agraria de La Vía Campesina ¿Quiénes somos? Luchadoras y luchadores por los territorios. Marabá-Brasil. 2016. Available online: https://viacampesina.org/es/ conferencia-internacional-de-la-reforma-agraria-declaracion-de-maraba/ (accessed on 8 June 2021).

15. La Vía Campesina, LVC. Las Luchas de La Vía Campesina. Por la Reforma Agraria, la Defensa de la Vida, la Tierra y los Territorios. 2017. Available online: https:/ /viacampesina.org/es/wp-content/uploads/sites/3/2017/10/Publication-of-Agrarian-ReformES.compressed.pdf (accessed on 8 June 2021).

16. Stronzake, J. Movimientos sociales, formación política y agroecológica. Rev. Am. Lat. Mov. 2013, 487, $27-29$.

17. Batista, A.F. Conciencia y Territorialización Contrahegemónica: Un Análisis de las Politicas de Formación de La Vía Campesina-América del Sur; Cultura Académica: Sao Paulo, Brasil, 2014.

18. Korol, C. "La formación Política en los Movimientos Populares Latinoamericanos" in OSAL; CLACSO: Buenos Aires, Argentina, 2007.

19. Michi, N. Movimientos Campesinos y Educación. Estudio sobre el Movimiento de Trabajadores Rurales Sin Tierra de Brasil y el Movimiento Campesino de Santiago del Estero MOCASE-VC; Colección Orlando Fals Borda; El Colectivo: Buenos Aires, Argentina, 2010.

20. Caldart, R.S. Pedagogía del Movimiento Sin Tierra; Expresión Popular: São Paulo, Brazil, 2004.

21. Caldart, R.S. El MST y la escuela: Concepción de educación y matriz formativa. In R.S. CALDART (org.) Caminos Para la Transformación de la Escuela: Reflexiones Desde Prácticas de la Licenciatura en Educación del Campo; Expresión Popular: Sao Paulo, Brazil, 2010.

22. Caldart, R.S. Escuela en Movimiento en el Instituto de Educación Josué de Castro, 1st ed.; Expresión Popular: São Paulo, Brazil, 2013.

23. Guelman, A. Pedagogía y Política: La Formación para el Trabajo en los Movimientos Sociales. El caso de la Escuela de Agroecología de MOCASE-V (2009-2012); Repositorio institucional de la Facultad de Filosofía y Letras de la Universidad de Buenos Aires: Buenos Aires, Argentina, 2015.

24. Palumbo, M.M. Conocimientos y saberes en dispositivos pedagógicos. La formación política en movimientos populares. Rev. Cienc. Soc. 2020, 33, 69-87.

25. Dalmagro, S. La Escuela en el Contexto de las Luchas del Movimiento. Tesis de Doctorado. Programa de Posgrado en Educación. Universidad Federal de Santa Catarina-UFSC. 2010. Available online: https://repositorio.ufsc.br/handle/123456789/94587 (accessed on 8 June 2021).

26. Casado Baides, B. Pedagogías Políticas Para Disputar Territorios. La Experiencia Educativa del MST. Fundación Betiko. 2020. Available online: http:/ / fundacionbetiko.org/la-experiencia-educativa-del-mst/ (accessed on 8 June 2021).

27. Rosset, P.M. La territorialización de la agroecología en la disputa de proyectos, y los desafíos para las escuelas del campo. In SOARES, D. et al. (org) La Agroecología en la Educación Básica: Cuestiones Propositivas de Contenido y Metodología; Otras Expresiones: Sao Paulo, Brazil, 2017; pp. 83-92.

28. Barbosa, P.L.; Rosset, P.M. Educación del campo y pedagogía campesina agroecológica en América Latina: Aportes de La Vía Campesina y de la CLOC. Revista Educación sociedad. Campinas 2017, 38, 705-724.

29. Holt-Giménez, E. Campesino a Campesino: Voices from Latin America's Farmer to Farmer Movement for Sustainable Agriculture; Food First Books: Oakland, CA, USA, 2006.

30. Val, V.; Rosset, P.; Zamora, C.; Giraldo, O.F.; Rocheleau, D. Agroecology and La Via Campesina, I. The symbolic and material construction of agroecology through the dispositive of "peasant-to-peasant" processes. Agroecol. Sustain. Food Syst. 2019, 43, 872-894. [CrossRef]

31. Rivera-Ferre, M.G. The resignification process of Agroecology: Competing narratives from governments, civil society and intergovernmental organizations. Agroecol. Sustain. Food Syst. 2018, 42, 666-685. [CrossRef]

32. Rivera-Ferre, M.G.; Gallar, D.; Calle-Collado, A.; Pimentel, V. Agroecological education for food sovereignty: Insights from formal and non-formal spheres in Brazil and Spain. J. Rural. Stud. 2021, 88, 138-148. [CrossRef] 
33. Freire, P. Pedagogía del Oprimido, 19th ed.; Siglo XXI: Madrid, Spain, 2007.

34. Asamblea Internacional de Mujeres de La Vía Campesina (AIMLVC). Declaración Política I Asamblea de Mujeres de La Vía Campesina, Bangalore. 2000. Available online: https://viacampesina.org/es/genero/ (accessed on 10 September 2021).

35. Asamblea Internacional de Mujeres de La Vía Campesina (AIMLVC). Declaración IV Asamblea de Mujeres de La Vía Campesina: Con Feminismo y Soberanía Alimentaria Cambiamos el Mundo, Yakarta. 2013. Available online: https://viacampesina.org/es/ manifiesto-internacional-de-las-mujeres-de-la-via-campesina-2/ (accessed on 10 September 2021).

36. Lima, M.M.; Brito de Jesus, V. Questions on gender and technology in the construction of the agroecology. Sci. Studia 2017, 15, 73-96. [CrossRef]

37. Viveros, M. La interseccionalidad: Una aproximación situada a la dominación. Debate Fem. 2016, 52, 1-17. [CrossRef]

38. Urretabizkaia, L. Interseccionalidad, soberanía alimentaria y feminismos de Abya Yala. Estudio de caso en Perú: FENMUCARINAP. Cuad. De Trab. Hegoa 2020, 85, 58.

39. Aguado, J.; Viñas, A.; Gallar, D. Escuelas campesinas para la Soberanía Alimentaria.Soberanía Aliment. Biodivers. Cult. 2014, 16, 23-26.

40. Gallar, D.; Acosta, R. Pro-peasant Resignification of Rurality: Rural University «Paulo Freire». Rev. Dialectol. Tradic. Pop. Vol. LXIX 2015, 2, 285-304.

41. Casado Baides, B. Procesos de Formación de Campesinos y Disputa Territorial Para Construir Soberanía Alimentaria. Análisis de Experiencias Impulsadas por Organizaciones de La Vía Campesina en Brasil y País Vasco. Ph.D. Thesis, University of Basque Country, Leioa, Spain, 2018.

42. Casado Baides, B. Sistematización de la experiencia Baserritik Mundura: Formación e Investigación para la Soberanía Alimentaria; Universidad del País Vasco: Bilbao, Spain, 2019. Available online: http://publicaciones.hegoa.ehu.es/es/publications/412 (accessed on 8 June 2021).

43. Gallar-Hernández, D. Forging Political Cadres for Re-Peasantization: Escuela de Acción Campesina (Spain). Sustainability 2021, 13, 4061. [CrossRef]

44. Instituto Técnico de Capacitação e Pesquisa da Reforma Agrária, ITERRA. Dossier MST and Escola. Documents and Studies 1990-2001. Cad. Educ. 2005, 13.

45. Ribeiro, M. Pedagogia da Alternância na educação rural do campo: Projetos em disputa. Educ. Pesqui. 2008, 34, 27-45. [CrossRef]

46. Verger, A. Sistematizando experiencias: Análisis y recreación de la acción colectiva desde la educación popular. Rev. Educ. 2007, $343,623-645$.

47. Jara, O. La Sistematización de Experiencias, Práctica y Teoría Para Otros Mundos Posibles; PDTG, CEAAL and Centre of Studies y Publications Alforja: Lima, Peru, 2014.

48. Jara, O. La Sistematización de Experiencias Produce un Conocimiento Crítico, Dialógico y Transformador. Revista Reflexiones pedagógicas. 2015. Available online: http://www.cepalforja.org/sistem/bvirtual/wp-content/uploads/2015/06/EntrevistaOscar-Jara-Revista-Docencia.pdf (accessed on 20 August 2021).

49. Torres, A. Producción de conocimiento desde la investigación crítica. Rev. Nómadas 2014, 40, 69-83.

50. Torres, A. La Sistematización como Investigación Participativa. In Procesos Y Metodologías Participativas: Reflexiones Y Experiencias Para La Transformación Social; Yáñez, P.P., Rébola, R., Elías, M.S., Eds.; CLACSO: Buenos Aires, Argentina, 2019 ; pp. 74-92.

51. Oñederra-Aramendi, A.; Begiristain-Zubillaga, M.; Malagón-Zaldua, E. El Centro de Acopio Sareko: Aprendizajes en la gobernanza de las Redes Agroalimentarias Alternativas para los saltos de escala. Rev. De Estud. Geográficos 2020, 81, e052. [CrossRef]

52. Urretabizkaia, L.; Arroyo, M. Feminismo en la Soberanía Alimentaria: Feminismo campesino, Guía 4 del curso Baserritik Mundura. 2018; unpublished work.

53. Urretabizkaia, L. Ampliando las miradas de la soberanía alimentaria y el feminismo hegemónico: Propuestas colectivas en las intersecciones de la cadena alimentaria. In Proceedings of the VI Congreso de Economía Feminista, Valencia, Spain, 5-7 September 2019; España Ámbito temático 3: Ecofeminismo. 2019, Unpublished work.

54. Alvarez Vispo, I.; Begiristain Zubillaga, M. Feminismo para los sistemas alimentarios y la agroecología. Rev. Iberoam. Econ. Solidar. Innovación Socioecológica 2019, 2, 125-146.

55. Rosenberg, M. Comunicación No Violenta. Un Lenguaje de Vida; Gran, A., Ed.; Gran Aldea Editores: Buenos Aires, Argentina, 2006. 